\title{
Antagonistic effectiveness of some bacteria against Fusarium graminearum causing crown rot disease on wheat (Triticum aestivum)
}

\author{
Majida Hadi Mahdi Alsaady ${ }^{1}$, Hussein Ali Salim ${ }^{2}$, Rakib A. Al-ani ${ }^{3}$, Hadi M. Aboud ${ }^{4}$ and \\ Jamal Talib M Al Roubaie ${ }^{5}$
}

${ }^{1}$ College of Science, University of Baghdad, Iraq

${ }^{2}$ Directorate of Diyala Agriculture, Ministry of Agriculture, Iraq

${ }^{3}$ College of Agriculture, University of Baghdad, Iraq

${ }^{4}$ Ministry of Science and Technology, Iraq

${ }^{5}$ Ministry of Education

${ }^{2}$ Corresponding author: $\underline{\text { h_salim11111@yahoo.com }}$

\begin{abstract}
In this study, the antagonistic effect of five bacteria genera namely Bacillus, Pseudomonas, Azotobacter, Azospirillum, and Streptomyces isolated from rhizosphere of wheat were evaluated against Fusarium graminearum as potential biocontrol agents in vitro. $F$. graminearum was molecularly diagnosed using the Polymerase chain reaction (PCR) technique. Each bacteria were tested for the production of catalase enzyme, oxidase enzyme, analysis of starch, analyze of gelatin, and the motility, where Azotobacter, Azospirillum, and Bacillus subtilis were positive for all tested. Fungal inhibition tests were performed by using the dual culture method and agar well diffusion technique. Among them, Streptomyces and Azospirillum exhibited potent inhibition to the growth of $F$. graminearum $(72.14 \%$ and $66.42 \%$ ) respectively, followed by B.pumillus, P.fluorescens, B. subtilis and Azotobacter ( $58.28 \%, 43.23 \%, 39.71 \%$ and $35.71 \%$ ) respectively as compared with the control treatment $(0.0 \%)$.The dry weight of the fungus biomass was decreased with bacteria $P$. fluorescens, Streptomyces sp, Azotobacter sp, Azospirillum sp, B. subtilis, and B. pumillus which reached $(0.114,0.103,0.147,0.101,0.143$, and $0.107 \mathrm{~g})$ respectively compared to the control treatment that was $0.665 \mathrm{~g}$.
\end{abstract}

Keywords: Fusarium graminearum, Azotobacter, Azospirillum, Streptomyces, Bacillus subtilis, and Bacillus pumillus

\section{Introduction}

The growth and development of plants are affected by plant diseases which result in a reduction in output and product quality (Salim et al., 2017). Fusarium graminearum is the most aggressive species against wheat plants through pathogenicity tests and causes extensive damage through losses in grain yield and grain contamination with mycotoxins (Cuilin, 2001). Symptoms on the spikes appear as brown water spots, which extend up and down and development of infection with the availability of appropriate temperature and moisture, besides the effect of the fungus on the production quantity, its effects on its quality, through the release of toxins in grains, which represent a high risk to humans and animals (Cook, 1981; Murray and Brennan, 2009; Obanora et al., 2013). The losses caused by the disease range from $30 \%$ to $50 \%$ in numerous cultivated areas in the world, including European

Dates: 
countries, America, West Asia, North Africa, Australia, and Canada (Moya et al., 2010; Arici, 2012). The followed procedures to control such disease was only depended on the use of chemical fungicides, but extensive use of these pesticides led to significant damage to the ecosystem, human health, and their livestock, as well as the emergence of pesticide-resistant strains (Rahman et al., 2003; Mohiddin and Khan, 2013). In recent decades Researchers' efforts have been directed towards finding alternatives to fungicides to manage such diseases, that are environmentally friendly, safe, and efficient, the focus was on the use of beneficial microorganisms in agricultural soils that can improve the soil properties to make them more suitable for plant growth by equipping them with the necessary nutrients and making them unsuitable for the growth of pathogens through the production of secondary metabolites substances (Tuzun and Kloepper, 1995; Pieterse and Van Loon, 2007; Zamanizadeh et al., 2010). Biological control by using antagonistic microbes still more significant due to it is environmentally friendly, safe, and sustainable (Dwi et al., 2010). This study was carried out to isolate some bacterial strains such as Bacillus, Pseudomonas, Azotobacter, Azospirillum, and Streptomyces from the rhizosphere of wheat to study their anti-fungal activities against $F$. graminearum in vitro.

\section{Materials and Methods}

The laboratory experiment, which included physical and chemical tests was conducted in the Biotechnology, Soil, and Microbiology laboratories of the Ministry of Science and Technology.

\section{Collect of samples}

Wheat plants Triticum aestivum cv. Barcelona were collected from wheat fields in ALQadisiyah province from different locations at a rate of 50 samples from each field from 20 /3/2013 until 31/3/2013. Collected plants showed yellowing symptoms accompanied by the dark brown coloration on the crown, stalk, and sheaths of leaves with few branches and turning of spikes to white color. Plants were dried at laboratory temperature of $25 \pm 2{ }^{\circ} \mathrm{C}$ with humidity not exceeding $10 \%$ and kept in paper bags for subsequent experiments.

\section{Isolation of pathogenic fungus}

Ten plants from each district was selected, then the crown of the wheat stem was cut into small pieces $(2 \mathrm{~mm})$ and sterilized superficially with $1 \%$ sodium hypochlorite solution for 3 minutes and washed twice with sterile distilled water to remove chlorine. The pieces were dried on sterile filter paper and transferred to the medium of potato dextrose agar (PDA) with adding $100 \mu \mathrm{g}$ of the antibiotic (tetracycline) in Petri dishes (each $9 \mathrm{~cm}$ ) and incubated at $25 \pm 2{ }^{\circ} \mathrm{C}$ for three days, pieces of mycelia were transferred by a sterile needle to PDA medium in Petri dishes (Barnett and Hunter, 1972).

\section{Purification of $F$. graminearum by single spore technique}

The single spore technique was used to obtain pure and genetically homogeneous cultures from fungus isolates. Three-four drops of distilled water were added to the growing fungus colony around the plant pieces on PDA medium, then part of the fungus suspension was transferred by sterile loop and spread on the surface of the medium (water agar) in Petri dishes $(9 \mathrm{~cm})$ and incubated at $25{ }^{\circ} \mathrm{C}$ with humidity $70 \%$ for 24 hours under continuous lighting. The macro conidia with the help of light microscopy was transferred to the PDA medium in Petri dishes and incubated at $25 \pm 2{ }^{\circ} \mathrm{C}$ for a week until the growth of fungus (Scott and Chakraborty, 2010).

\section{Pathogenicity test of $F$. graminearum isolates}


The pathogenicity test of four isolates of $F$. graminearum (F.g Q10, F.g Q20, F.g Q30, and F.g Q40) was carried out. The soil was sterilized by autoclave at $121^{\circ} \mathrm{C}$ and a pressure of 1.5 $\mathrm{kg} / \mathrm{cm}^{2}$ for an hour and re-sterilized under the same conditions in the next day. Pots $(15 \mathrm{~cm}$ diameter) were filled with sterile soil and infested with a half Petri dish $(9 \mathrm{~cm})$ of fungal isolate for each pot and then covered with polyethylene bags for two days. Wheat seeds cv. Barcelona were sterilized superficially by immersing them in $2 \%$ sodium hypochlorite solution for 2 minutes. The seeds were then washed with sterile distilled water and planted in pots 10 seeds/pot. The pots were randomly distributed with three replicates and RCBD design and watered with water whenever needed. The pots were daily monitored to record any observations such as the appearance and development of any symptoms. Seed germination percentage, infection ratio, and disease severity were calculated.

\section{Diagnosis of the fungal isolate using Polymerase chain reaction (PCR) technique}

This technique was carried out in the laboratory of the molecular test at the Ministry of Science and Technology to diagnose the isolated fungus according to the following steps:

\section{DNA extraction}

A small amount $(0.2-0.5 \mathrm{mg})$ of mycelia of F.g Q10 isolate was transferred to a ceramic mortar to add $500 \mu \mathrm{l}$ of DNA extraction CTAB Buffer (Cetyl Trimethyl Ammonium Bromide) $2 \%$, thereafter a similar volume of liquid nitrogen was added to the mixture and crushed well, with help of a pestle. Subsequently, the extract was transferred to an Eppendorf tube $(1.5-2 \mathrm{ml})$ and incubated in a water bath at $55^{\circ} \mathrm{C}$ for 15 minutes with shaking the tube using a vortex device, then centrifuged at a speed of $12000 \mathrm{rpm}$ (Graham et al., 1994).

\section{Precipitation and purification of DNA}

For precipitation and purification of DNA, chloroform and isoamyl alcohol (250 $\mu \mathrm{l})$ were added to the supernatant liquid at a ratio of 1:24 and mixed thoroughly and centrifuged at a speed of $12000 \mathrm{rpm}$ for one minute. The top layer that contains the DNA was transferred to new tubes; ammonium acetate $(7.5 \mathrm{Mol})$ and one volume of cold absolute ethanol were added to each tube to a tenth of its volume (1/10). The solution was gently mixed several times and centrifuged at a speed of $12000 \mathrm{rpm}$ for one minute for DNA precipitation. Precipitated DNA was washed by adding 500 $\mu$ l of cold ethanol alcohol (70\%) with slowly stirring and centrifuged at $12.000 \mathrm{rpm}$ for one minute and left at laboratory temperature to remove the residue of alcohol. Fifty $\mu \mathrm{l}$ of Tris-EDTA buffer (TE) was added to each sample and left at room temperature for one minute and then centrifuged at $12.000 \mathrm{rpm}$ for one minute to collect DNA and kept at $-10{ }^{\circ} \mathrm{C}$ for subsequent tests (Saitoh et al., 2006).

\section{Measurement of concentration and purity of DNA}

Absorption of an extracted DNA sample was measured at the wavelengths $280 \mathrm{~nm}$ and 260nm using a drop spectrophotometer nano device (American Thermo Scientific Company) and according to the DNA concentration and according to the following equation:

Concentration $(\mathrm{mg} / \mathrm{ml})=$ Absorption at $260 \mathrm{~nm} \times 100($ dilution coefficient $) \times 50($ Sambrook et al., 1989).

\section{Polymerase chain reaction (PCR) technique}

The PCR technique was used to diagnose the fungus to the species level, the primers and the sequence of nitrogenous bases were used as described in Tables 1 and 2 . The reaction mix from (Bioneer.com, Korea company) was prepared in the small tubes (volume $500 \mu \mathrm{l}$ ) to be $16 \mu 1$ of sterile distilled water and $2 \mu 1$ buffers and $2 \mu 1$ of DNA samples with concentration 25-50 ng. $\mu \mathrm{L}^{-1}$ to become the final volume $20 \mu \mathrm{L}$, then mixed well and centrifuged by vortex 
centrifuge at a speed of $3000 \mathrm{rpm}$ for three minutes. the PCR tube was then placed in a PCR Thermocycler and the conditions and steps of PCR amplification was follows:

PCR products were analyzed on agarose gel $(1.5 \%)$ by electrophoresis technique and examined under UV transillumination and images were captured.

Table 1. The primers

\begin{tabular}{|l|c|l|c|}
\hline Species of Fusarium & Primers & \multicolumn{1}{|c|}{$\begin{array}{c}\text { Sequence of nitrogenous bases } \\
(\mathbf{3} \text { - 5) }\end{array}$} & $\begin{array}{c}\text { Number } \\
\text { of bases }\end{array}$ \\
\hline \hline F.culmorum & FcOIF & 3ATGGTGAACTCGTCGTGGC & 19 \\
& FcOIR & CCCTTCTTACGCCAATCTCG & 20 \\
\hline \hline F.pseudograminearum & Fp1-1 & CGGGGTAGTTTCACATTTCCG & 21 \\
& Fp1-2 & GAGAATGTGATGACGACAATA & 21 \\
\hline \hline F.graminearum & Fg16NF & ACCAGATGACAAGATTCAGGCACA & 23 \\
& Fg16NR & TTCTTTGACATCTGTTCAACCCA & 23 \\
\hline
\end{tabular}

Table 2. Sources of primers

\begin{tabular}{|l|l|}
\hline Primers & Reference \\
\hline \hline FcoIF,FcOIR & Nicholson et al, 1998 \\
\hline \hline Fp1-1,Fp1-2 & Aoki and O'Donnell, 1999 \\
\hline Fg16NF,Fg16NR & Nicholson et al, 1998 \\
\hline
\end{tabular}

\section{Electrophoresis technique}

Electrophoresis tank was used with the agarose gel tray and the comb to make agarose gel. The agarose gel at a concentration of $1 \%$ was prepared by dissolving $1 \mathrm{~g}$ of agarose in 1000 $\mathrm{ml}$ of TE solution with $\mathrm{pH} 8$, the gel was poured in the loading board continuously and slowly to avoid the formation of air bubbles and leave the gel at the laboratory temperature to harden, the comb was picked up slowly and place the gel in the basin then submerged with the TBE solution, the samples were prepared for electrophoresis by mixing of DNA for each treatment with buffer at ratio 1: $3 \mu$, the samples were distributed to the wells by using a Micropipette, the device was locked and the electrodes were connected and the electrophoresis was carried out at $100 \mathrm{~V}$ for an hour and a half. When the blue dye reached the end of the gel, the electrophoresis was stopped.

\section{Isolation of bacteria}

Bacteria were isolated according to the method described by Wollum, (1982) Collee et al. (1996) Macfaddin (2000). Wheat plants were uprooted and the soil around the roots was collected and milled well. ten $\mathrm{g}$ of soil and $90 \mathrm{ml}$ of Peptone water that consist of $5 \mathrm{~g}$ peptone, $5 \mathrm{~g}$ Treptone, $5 \mathrm{~g}$ Sodium Chloride, and one L. water were added and then the mixture was mixed using an electric shaker at a speed of $120 \mathrm{rpm} / \mathrm{min}$ for 30 minutes and left to stagnate. One $\mathrm{ml}$ of the supernatant was taken and nine $\mathrm{ml}$ of the saline solution $(\mathrm{NaCl})$ at a concentration of $0.85 \%$ was added to obtain the second decimal dilution then the third decimal dilution. Thereafter, $0.1 \mathrm{ml}$ from dilution $\left(10^{-3}\right)$ and disseminated to Petri dishes containing a selective medium for each species of bacteria such as Bacillus, Pseudomonas, Azotobacter, Azospirillum, and Streptomyces. All Petri dishes were incubated at $30^{\circ} \mathrm{C}$ for 48 hours. The bacterial isolates were grown at $25 \pm 2{ }^{\circ} \mathrm{C}$ in slant cultures containing nutrient agar medium (NA) and preserved at $4^{\circ} \mathrm{C}$, Nutrient broth medium (NB) was used for bacterial growth and other laboratory tests. 


\section{Bacterial media}

\section{P. fluorescens}

The medium of Pseudomonas agar base was consisted of $16 \mathrm{~g}$ of Pancreatic digest of gelatin, $10 \mathrm{~g}$ Casein enzymic hydrolysate, $10 \mathrm{~g}$ Potassium Sulfate, $1.4 \mathrm{~g}$ Magnesium Chloride anhydrous, $11 \mathrm{~g}$ Agar, and $500 \mathrm{ml}$ Water. This medium was inoculated with bacteria by the streaking method and incubated at $30^{\circ} \mathrm{C}$ for 24 hours (Wollum, 1982).

\section{Streptomyces}

The medium of yeast malt extract (YME), which consists of $4 \mathrm{~g}$ Yeast extract, $5 \mathrm{~g}$ Peptone, $20 \mathrm{~g}$ malt extract, $4 \mathrm{~g}$ glucose, $17 \mathrm{~g}$ sucrose, $10 \mathrm{~g}$ Agar, and one liter distilled water with $\mathrm{pH}=7$. this medium was inoculated with part of a colony already growing on medium (NA) and incubated at $28{ }^{\circ} \mathrm{C}$ for 4-6 days. To test the bacteria ability for growth in the saline medium by adding $\mathrm{NaCl}$ to the medium at a rate of $7 \%, 8 \%$, and $10 \%$ (Miyadoh, 1993). the bacterial ability to produce catalase enzyme was tested by adding $3 \% \mathrm{H}_{2} \mathrm{O}_{2}$ to the medium, then inoculated. The bacteria were considered positive to the test if they were able to produce bubbles and wheezing. Whereas, the motility of bacteria was also tested using the (Add a reference).

\section{Azotobacter}

The N-free medium agar consists of $10 \mathrm{~g}$ glucose, $1 \mathrm{~g} \mathrm{~K}_{2} \mathrm{HPO}_{4}, 0.2 \mathrm{~g} \mathrm{MgSo}_{4} .7 \mathrm{H}_{2} \mathrm{O}, 0.05 \mathrm{~g}$ $\mathrm{FeSo}_{4} \cdot 7 \mathrm{H}_{2} \mathrm{O}, 0.001 \mathrm{~g} \mathrm{Na}_{2} \mathrm{MoO}_{4} \cdot 2 \mathrm{H}_{2} \mathrm{O}, 0.1 \mathrm{~g} \mathrm{CaCl}_{2}, 15 \mathrm{~g}$ agar, was dissolved in 1liter of distilled water, and the $\mathrm{pH}$ adjusted to 7.2 -7.3. The medium was then autoclaved at a temperature of $121^{0} \mathrm{C}$ and a pressure of $1.5 \mathrm{~kg} / \mathrm{cm}^{2}$ for 20 minutes, then the bacteria in Petri dishes were incubated at $25 \pm 2{ }^{\circ} \mathrm{C}$ for $48-72$ hours. The shape and characteristics of the bacterial colony were observed on the Petri dish through convexity, texture, and color. Thereafter, the colony was checked by light microscope to identify cell shape and cyst formation (Harold et al., 1998).

\section{Azospirillum}

The medium of nitrogen-free bromothymol blue consists of $5 \mathrm{~g}$ Malic acid, $0.02 \mathrm{~g} \mathrm{CaCl}_{2}$, $0.015 \mathrm{~g} \mathrm{FeCl}_{3} .6 \mathrm{H}_{2} \mathrm{O}, 0.5 \mathrm{~g} \mathrm{~K}_{2} \mathrm{HPO}_{4}, 4.5 \mathrm{~g} \mathrm{KOH}, 0.2 \mathrm{~g} \mathrm{MgSO}_{4} \cdot \mathrm{H}_{2} \mathrm{O}, 0.01 \mathrm{~g} \mathrm{MnSO}_{4} . \mathrm{H}_{2} \mathrm{O}$, $0.002 \mathrm{~g} \mathrm{Na}_{2} \mathrm{MOO}_{4} . \mathrm{H}_{2} \mathrm{O}, 0.1 \mathrm{~g} \mathrm{NaCl}, 0.0001 \mathrm{~g}$ Biotin, $2 \mathrm{ml}$ Bromothymol blue, $17 \mathrm{~g}$ Agar, 0.02 g Yeast extract, $1.0 \mathrm{~g} \mathrm{NH}_{4} \mathrm{Cl}$, 1 liter distilled water with $6.8 \mathrm{pH}$, was used (Krieg and Dobereiner, 1984). The sterilized medium was inoculated with bacteria and incubated at $32^{\circ} \mathrm{C}$ for 48 hours. The appearance of the ring growth (pellicle) with white color at a distance of 1-4 $\mathrm{mm}$ below the surface after 24 hours, which rises to a distance of $2 \mathrm{~mm}$ from the surface after 48 hours. Such characteristics can indicate the existence of bacteria Azospirillum. The colony was checked by a light microscope to determine the shape and capacity of the cells on the movement (Dobereiner and Day, 1976).

\section{Bacillus subtilis and Bacillus pumillus}

Nutrient agar and nutrient broth were used to study the growth nature of the bacteria and the shape of colonies on these media. These media were prepared following the manufacturer's company instructions. Sterilized by autoclave at $121^{\circ} \mathrm{C}$ and a pressure of 1.5 $\mathrm{kg} / \mathrm{cm}^{2}$ for 15 minutes. The nutrient broth was sterilized and used to prepare the bacterial filtrate for laboratory tests. Nutrient agar was used to preserve the purified isolates at $-4{ }^{\circ} \mathrm{C}$.

\section{Diagnosis of bacteria}

The bacterial species were diagnosed in the Microbiology laboratory based on the characteristics of the growing colonies on their electoral medium such as their color, shape, 
convexity, luminosity, edge, viscosity, cell shape, and their response to gram stain and the collect method and spore formation using light microscopy (Bergey's Manual, 1985).

\section{Gram Stain}

The gram stain was used for the $\mathrm{CDH}$ company to distinguish between gram-positive bacteria $(\mathrm{G}+\mathrm{Ve})$ and gram-negative bacteria $(\mathrm{G}-\mathrm{Ve})$.

\section{Biochemical tests}

\section{The ability of bacteria to produce the Catalase enzyme}

A few drops of the catalase enzyme reagent consisting of $(3 \%)$ hydrogen peroxide $(\mathrm{H} 2 \mathrm{O} 2)$ were added to the colonies of bacteria that grow on the nutrient agar medium (Baron and Finegold, 1990). Production of air bubbles refers that these bacteria can produce catalase enzymes.

\section{The ability of bacteria to produce brilliant pigments}

Using the King $\mathrm{B}$ medium, which was prepared by dissolving $20 \mathrm{~g}$ peptone, $1.5 \mathrm{~g}$ $\mathrm{MgSO}_{4} .7 \mathrm{H}_{2} \mathrm{O}, 1.5 \mathrm{~g} \mathrm{~K}_{3} \mathrm{PO}_{4}, 10 \mathrm{ml}$ glycerol, and $15 \mathrm{~g}$ agar in 1 liter of distilled water with 7.2 $\mathrm{pH}$ and sterilized by autoclave. To investigate the production of fluorescent pigments, the medium was inoculated with bacteria and incubated at $28 \pm 2^{\circ} \mathrm{C}$, where the emergence of a fluorescent pigment when colonies are exposed to the UV is a diagnostic characteristic of bacteria from the fluorescent group (Stolp and Gadkari, 1984).

\section{The ability of bacteria to analyze starch}

Using agar-starch for this test, where the medium was prepared by adding $2 \%$ starch to the nutrient broth medium and sterilized, the medium was poured in the Petri dishes, and then inoculated with bacteria at the age of 24 hours and incubated at $37{ }^{\circ} \mathrm{C}$ for $2-5$ days. The dishes were submerged with Lugol's solution, where the emergence of transparent areas around colonies is a positive consequence for the ability of bacteria to starch analysis (Benson, 1998). The medium was also used to differentiate between B. subtilis and B. pumillus .

\section{The ability of bacteria to analyze gelatin}

Using the gelatin medium in this test, where the medium was prepared by dissolving $12 \mathrm{~g}$ gelatin and $1.3 \mathrm{~g}$ nutrient broth in $90 \mathrm{ml}$ distilled water and complete the volume to $100 \mathrm{ml}$ and then sterilized by autoclave .The medium was used to detect the ability of bacteria to produce gelatinase enzyme (Stolp and Gadkari, 1984).

\section{The ability of bacteria to produce oxidase enzyme}

The method previously described by Baron and Finegold (1990) was used to detect the ability of bacteria to produce cytochrome oxidase enzyme, a filter paper was submerged with oxidase reagent solution (1\% Tetramethyl Para-Phenyl Diamine-Dehydrochloride). Thereafter, a bacterial colony was transferred to this paper by a sterile wooden stick, where the appearance of produced gray color during 15-60 seconds indicates the ability of bacteria to produce the cytochrome oxidase enzyme.

\section{The ability of bacteria to the motility}

Tubes containing semi-solid agar medium ( $8 \mathrm{~g}$ agar to $1 \mathrm{~L}$.) were prepared and inoculated with bacteria by the method of acupuncture and incubated at $28 \pm 2{ }^{\circ} \mathrm{C}$ for $72 \mathrm{~h}$. The growth and spread of bacteria around the acupuncture area indicate the ability of those bacteria to motility (Cruickshank et al., 1975). 


\section{Filtration of bacterial cultures}

The bacterial species were grown individually in the nutrient broth medium in glass flasks (each $250 \mathrm{ml}$ ) containing $100 \mathrm{ml}$ of the medium, Each flask was inoculated with an amount of bacterial growth and incubated at $25^{\circ} \mathrm{C}$ in a shaker incubator at 150 shakes per minute for one-five days. Bacterial cultures were filtered through the Millipore filter membranes with an opening diameter of $0.45 \mu \mathrm{m}$ with aim of an air vacuum.

\section{Antagonistic effectiveness of bacteria against $F$. graminearum using dual culture method}

After pouring the PDA medium into Petri dishes $(9 \mathrm{~cm})$ and allowed to solidify, putting a line of bacterial growth by a needle for each bacteria individually at one side of the dish with a distance of one $\mathrm{cm}$ from the edge, then transferring an agar disk $(0.5 \mathrm{~cm})$ from the tip of the $F$. graminearum colony (five days old) on the other side of the same dish. The Petri dishes that contain only the fungus were used as a control treatment. All Petri dishes were incubated at $25 \pm 2{ }^{\circ} \mathrm{C}$ until the growth of the pathogen reached the edge of the Petri dish. The percentage of inhibition was then calculated according to the following formula:

$\%$ Inhibition $=$ growth rate in the control - growth rate in treatment/growth rate in the control $\times 100$.

\section{Antagonistic effectiveness of bacteria against $F$. graminearum using the agar well diffusion technique}

Wells (each $0.5 \mathrm{~cm}$ in diameter) were made in PDA using a sterile cork borer into Petri dishes $(9 \mathrm{~cm})$ close to the edges ( four wells/ plate). Nutrient agar $(0.05 \mathrm{ml})$ was placed in each well, and one $\mathrm{ml}$ of bacterial filtrate for each bacteria was added to each well. Then, an agar disk $(0.5 \mathrm{~cm})$ from the tip of the $F$. graminearum colony (five days old) was transferred to the center of the dish. Distilled water was added instead of the bacterial filtrate as a control treatment. All Petri dishes were incubated at $28 \pm 2{ }^{\circ} \mathrm{C}$ until the growth of $F$. graminearum reached the edge of the Petri dish. After 72 hours of incubations, the diameter growth rate and the percentage of inhibition was calculated according to the following formula:

$\%$ Inhibition $=$ growth rate in the control treatment - growth rate in the treatment/growth rate in the control treatment $\times 100$.

\section{Effect of bacteria filtrate on the dry weight of $F$. graminearum}

The dry weight of the biomass of $F$. graminearum in the liquid medium was determined by the growth of the tested bacterial species on the nutrient broth according to their perfect growth period. Bacterial cultures were filtered through the Millipore filter membranes $(0.45$ $\mu \mathrm{m})$ with the help of the air vacuum device to ensure the rapid separation of bacterial cells from the filtrate. Each bacterial filtrate was inoculated with an agar disk $(0.5 \mathrm{~cm})$ from the tip of the $F$. graminearum colony five days old and Petri dishes were incubated at $28 \pm 2{ }^{\circ} \mathrm{C}$. The medium was filtered with filter paper Whatman (No. 2), then the filter papers were dried and weighed according to the biomass weight of the fungus. The biomass weight of the fungus was calculated according to the following formula:

Biomass weight $=$ Biomass weight with filter paper-dry weight of filter paper

\section{Results and Discussion}

Results, given in Table (3), showed that the high pathogenicity found in the isolates F.gQ10, F.gQ20, F.gQ30, and F.gQ40 isolated from infected wheat plants grown in some fields of Al-Qadisiyah province. The F.gQ10 isolate was significantly superior in pathogenicity compared to the other isolates (F.gQ20, F.gQ30, and F.gQ40), where infection ratio, disease severity, and germination ratio reached $82.22 \%, 82.03 \%$, and $36.67 \%$, 
respectively. The variation of the $F$. graminearum isolates in pathogenicity may be due to the genetic variations in the responsible genes linked with the pathogenicity (add a reference ${ }_{(\mathrm{s})}$ ). The ability of isolates to cause diseases is dependent on environmental conditions, host, sensitive phase, and plant density, also any change in these conditions lead to some genetic variation in the fungus (Smiley et al., 2005). Such genetic vibrations may give some differences in the ability of the isolates to produce some responsible enzymes causing diseases such as pectinase enzyme, which analyzes cuticle and cell wall wax, as well as the production of secondary metabolic compounds, including the toxins Deoxynivalenol (DON) and Nivalenol (NIV) (Kitkot et al., 2009; Paper et al., 2010).

Table 3. Pathogenicity of $F$. graminearum isolates included Infection ratio (\%), disease intensity \%, and germination ratio $(\%)$ of wheat plants

\begin{tabular}{|l|c|c|c|}
\hline Fusarium isolates & $\begin{array}{c}\text { Infection ratio } \\
(\%)\end{array}$ & $\begin{array}{c}\text { Disease severity } \\
(\%)\end{array}$ & $\begin{array}{c}\text { Germination ratio } \\
(\%)\end{array}$ \\
\hline \hline F. graminearum Q10 & 82.22 & 82.03 & 36.67 \\
\hline \hline F. graminearum Q20 & 41.27 & 40.21 & 60.00 \\
\hline \hline F. graminearum Q30 & 34.36 & 33.13 & 70.00 \\
\hline \hline F. graminearum Q40 & 43.69 & 41.62 & 66.67 \\
\hline \hline LSD 0.05 & 26.43 & 2.613 & 22.41 \\
\hline
\end{tabular}

F. graminearum Q10 was diagnosed through Polymerase chain reaction (PCR) using specific primer pairs. PCR products that run through electrophoresis on agarose gel $(1.5 \%)$ showed the presence of PCR products with the size of $280 \mathrm{bp}$ when the primer pair used (Fig 1).

The prevalence of $F$. graminearum as a causative agent of crown rot disease in Iraq is due to the appropriate environmental conditions. Backhouse and Burgess (2002) noted that this species prevails in hot and semi-dry regions. $F$. graminearum previously recorded in the rainy areas as a pathogen of root rot in Iraq (Al-Rashidi, 2011) and the irrigated areas (Alwan, 2005). In a diagnostic study of the root pathogens of barley root rot and its control in Nineveh province in 2013, were found the most common fungus is $F$. graminearum (Al-Kubaisi, 2013).

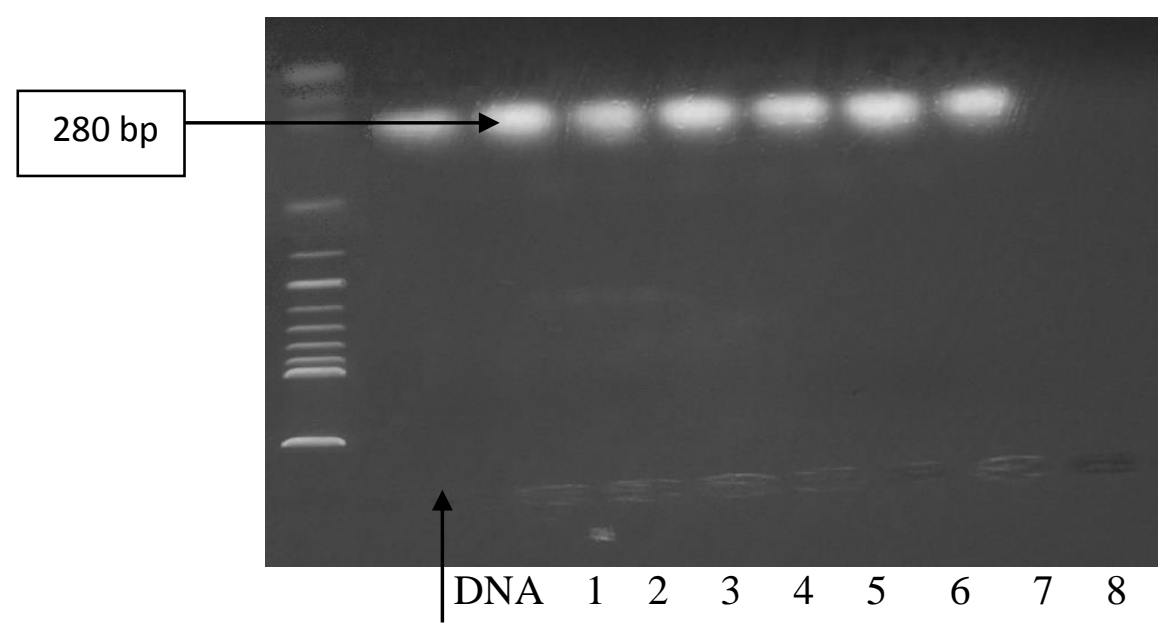

Fig 1. PCR products were amplified from the F. graminearum isolated in this study. $M=$ DNA ladder marker with sizes in base pair (bp) given on the left side of the figure

Results of bacteria characteristics showed the bacterial cell shape and their response to gram stain and biochemical tests on the cultural media (Table 4). 
Table 4. Biochemical tests of bacteria

\begin{tabular}{|l|c|c|c|c|c|c|}
\hline Bacteria & $\begin{array}{l}\text { Gram } \\
\text { Stain }\end{array}$ & $\begin{array}{l}\text { Analyze } \\
\text { of starch }\end{array}$ & $\begin{array}{l}\text { Analyze } \\
\text { of gelatin }\end{array}$ & $\begin{array}{l}\text { Catalase } \\
\text { enzyme }\end{array}$ & $\begin{array}{l}\text { Oxidase } \\
\text { enzyme }\end{array}$ & Motility \\
\hline \hline P.fluorescens & - & + & + & + & + & + \\
\hline \hline Streptomyces & + & + & + & + & - & - \\
\hline \hline Azotobacter & - & + & + & + & + & + \\
\hline \hline Azospirillum & - & + & + & + & + & + \\
\hline \hline B. subtilis & + & + & + & + & + & + \\
\hline \hline B. pumillus & + & - & + & - & - & + \\
\hline
\end{tabular}

Results in Table 5 indicate that all tested bacteria led to inhibition of the growth of $F$. graminearum on the culture medium. Streptomyces and Azospirillum were significantly superior in inhibition of fungus $(72.14 \%$ and $66.42 \%)$ respectively followed by $B$. pumillus , P. fluorescens, B. subtilis, and Azotobacter (58.28\%, 43.23\%, 39.71\%, and 35.71\%, respectively) compared with the control treatment. as shown in Table (3), it was noticed that a significant decrease in dry weight of the fungus biomass with bacteria $P$. fluorescens, Streptomyces, Azotobacter, Azospirillum, B. subtilis, and B. pumillus which reached 0.114, $0.103,0.147,0.101,0.143$, and $0.107 \mathrm{~g}$, respectively compared with the control traetment $(0$. $665 \mathrm{~g}$ ). Nourozian et al. (2006) indicated that in dual culture test and agar well diffusion technique for $F$. graminearum fungus with isolates of bacteria Streptomyces, B. subtilis, $P$. fluorescens, which led to inhibit the growth of fungal mycelium at 97-37\% with a clear superiority of Streptomyces bacteria. It was found in a previous study, there was an ability to produce antibiotics such as Tubercidin, Phosphlactomcin and Candicidin (Hwang et al., 1994). Previous studies indicated the efficacy of the bacteria Azospirillum, Azotobacter, P.fluorescens, B.pumillus, and B.subtilis in reducing the growth of $F$. graminearum in antagonistic tests on the culture medium (Abdulkareem et al., 2014). No difference was observed between the dual culture test and the agar well diffusion technique in the inhibition ratio of $F$. graminearum by different bacteria.

Table 5. The effect of bacteria on $F$. graminearum in inhibition ratio and dry weight of the fungus biomass

\begin{tabular}{|l|c|c|}
\hline Treatments & \% Inhibition & $\begin{array}{l}\text { Dry weight of the } \\
\text { fungus biomass } / g\end{array}$ \\
\hline \hline Control & 0.00 & 0.665 \\
\hline \hline P. fluorescens $+F$. graminearum & 43.23 & 0.114 \\
\hline \hline Streptomyces + F. graminearum & 72.14 & 0.103 \\
\hline \hline Azotobacter $+F$. graminearum & 35.71 & 0.147 \\
\hline \hline Azospirillum + F. graminearum & 66.42 & 0.101 \\
\hline \hline B. subtilis + F. graminearum & 39.71 & 0.143 \\
\hline \hline B. pumillus + F. graminearum & 58.28 & 0.107 \\
\hline \hline LSD 0.05 & 8.509 & 0.0026 \\
\hline
\end{tabular}

\section{Conclusion}

According to this research work, the isolated bacteria from soil that surrounded wheat roots (Bacillus, Pseudomonas, Azotobacter, Azospirillum, and Streptomyces) showed antagonistic effectiveness against $F$. graminearum growth in vitro, therefore can be used as biocontrol agents in future research, which will reduce the environmental effects of pesticides. 


\section{Acknowledgments}

The authors wish to thank Baghdad University, College of Agriculture for Awarding the opportunity to accomplish this work.

\section{Conflict of Interest}

The authors hereby declare no conflict of interest.

\section{References}

Abdulkareem, M., H. M. Aboud, H. M. Saood and M. K. Shibly. 2014. Antagonistic Activity of Some Plant Growth Rhizobacteria to Fusarium graminearum . International Journal Phytopathology. 03 (01): 49-54.

Al-Kubaisi, A. S. M. 2013.Diagnosis of pathogens of root rot of barley in the areas of Tal Afar and Hamdaniya and their control, Master Thesis, Department of Plant Protection, Faculty of Agriculture and Forestry, University of Mosul.

Al-Rashidi, W. A. S. 2011. Biological control of root rot and smut of wheat in non-tillage soils, Master Thesis, Department of Plant Protection, Faculty of Agriculture and Forestry, University of Mosul.

Alwan, S. L. 2005. The possibility of manufacturing a biocide from the fungus Trichoderma harzianum Rifai to control seed rot disease and seedling death in wheat, $\mathrm{PhD}$ thesis, College of Education for Girls, University of Kufa.

Arici, S. E. 2012. Screening of wheat varieties for their susceptibility against Fusarium crown rot . Journal of Food, Agriculture \& Enviroment. Vol. 10 (3\&4): 404-408 .

Backhouse, D. and L. W. Burgess. 2002. Climatic analysis of the distribution of Fusarium gramineaum, $F$. pseudograminearum and $F$. culmorum on cereals in Australia. Australasian Plant Pathology. 31: 321-327.

Barnett , H. L. and B. B. Hunter. 1972. Illustrated genera of imperfect fungi. $3^{\text {rd }}$ edition, Burgess publishing Company, Minneaposis. Minnesota.

Baron, E. and S. Finegold.1990. Bailey and Scott's diagnostic microbiology, 8th ed. The Mosby Company, St. Louis, MO.1990.

Benson, H.J. 1998. Microbiological Application - Laboratory Manual in General Microbiology. $7^{\text {th }}$ Edition. WCB McGraw - Hill, New York.

Bergey's Manual of Systematic Bacteriology (1985). Book Review [permanent dead link] Int. J. of Syst. Bact.; July, p. 408.

Collee, J.G., A.G.Fraser, B.P. Marmison and S.A. Simpson. 1996. Mackie and Macartneys. Practical medical microbiology $.14^{\text {th }}$ ed. Churchill Livingstone, UK.

Cook, R. J. 1981. Fusarium diseases of wheat and other small grains in North America . In Nelson, P. E., Taussoun, T.A. and Cook, R.J. (eds) Fusarium Diseases, Biology and Taxonomy . The Pennsylvania State University Press University park pp39-52 .

Cruickshank, R., J. Duguid, B. Marimon and R. Swain. 1975. Medical Microbiology the Practice of Medical Microbiology . Vol.2. $12^{\text {th }}$ edition, Churchill Livingstone ,UK .

Cuilin, Yi. (2001). Management of Fusarium graminearum-inoculated crop residues - Effects on head blight, grain yield and grain quality of subsequent winter wheat crops, Dissertation of Ph.D ,der Universität Hohenheim, Stuttgart, Germany.

Dobereiner, J. and L. Day. 1976 . Associative symbiosis in tropical grasses: Characterization of microorganisms and dinitrogen fixing sites. In proceeding First International Symposium on niterogen fixation (W .E. and C.J. Nyman, Eds .), PP. 518-538 Washington state University press, Pullman . 
Dwi S, Siti P, Erman M. 2010. Control of Fusarium Wilt of Chili with Chitinolytic Bacteria. Hayati J. Biosci. 17. 5-8.

Graham, G.C., P. Mayers, and R.J. Henry. 1994. A simple and rapid method for preparation of fungal genomic DNA for PCR and RAPD analysis . Biotechniques, 16, 48-50 .

Harold, J. B., W. C. B. and M. C. Grawlt. 1998 . Microbiological applications laboratory manual in general microbiology. Seventh Edition.

Hwang, B. K., S. J. Ahn. and S. S. Moon. 1994. Production, purification, and antifungal activity of the antibiotic nucleoside, tubercidin, produced by Streptomyces violaceoniger . Can. J. Bot., 72: 480-485.

Kitkot , G. E., R. A. Hours and T. M. Alconada. 2009. Contribution of cell wall degrading enzymes to pathogenesis of Fusarium graminearum: Review. Journal of Basic Microbiology. 49: 231-241.

Krieg, N.R and J. Dobereiner. 1984. Genus Azospirillum . Inikrieg, N.R and Holt, J.G.(eds). Bergey's Manual of systemic Bacteriology , 1:94-104. Williams and Wilkins, Baltimore - London .

Macfaddin, J. F. 2000. Biochemical tests for identification of medical bacteria, $3^{\text {rd }}$ edition. Lippicott Williams and Wilkins . USA.

Miyadoh, S. 1993. Research on antibiotic screening in Japan over the last decade: A producing microorganisms approach. Actinomycetologica. 1993;9:100-106.

Mohiddin , F.A. and M.R. Khan. 2013. Tolerance of pesticides commonly used in the control of soil borne pathogens. African Journal of Agricultural Research. 8: 5272- 5275.

Moya, E. A. 2010. Distribution and interaction of Fusarium crown rot and common root rot pathogens of wheat in Montana and development of an integrated management program for Fusarium crown rot. A thesis. Montana state United.

Murray, G. and J. Brennan. 2009. Estimating disease losses to the Australian wheat industry. Australasian Plant Pathology 38: Issue 6, pp 558-570.

Nourozian, J., H. R. Etebarian and G. Khoda Karamian. 2006. Biological control of Fusarium graminearum on wheat by antagonistic bacteria, Songklanakarin J. Sci. and Technol., 28: 29-38.

Obanora, F., S. Neateb, S. Simpfendorferc, R. Sabburga, P. Wilsond and S.Chakraborty.2013. Fusarium graminearum and Fusarium pseudograminearum caused 2010 head blight epidemics in Australia. Plant Pathology 62. 79-91.

Paper, J. M., J. S. Scott-Craiy, N. D. Adkikari, C. A. Cuomo and J. D. Walton. 2010. Comparative proteomics of extracellular proteins invitro and in plant from pathogenic fungus Fusarium graminearum . Cell and Molecular Biology 7:3171-3183.

Pieterse, C. M. and L. C. Van Loon. 2007. Signaling cascades Involved in induced resistance. In D. Walters, A. Newton and G. Lyon (eds) . Induced resistance for plant disease control : A sustainable approach to crop protection ( pp65-88) . Oxford U.K : Black Well .

Pikovskaya , R I.1948. Mobilization of phosphorus In soil in connection with the vital activity of some microbial species. Mikrobiologiya .17:362-370.

Rahman, M.M., Kim, E. Rhee and J. Kim. 2003. Effect of the fungicide Chlorothalonil on microbial activity and Nitrogen Dynamics in soil Ecosystem. Agric. Chem.. Biotechnol. 46: 169-173.

Saitoh, K.I., Togashi, K., Arie, T., Teraoka, T. 2006. A simple method for a mini-preparation of fungal DNA. J. Gen. Plant Pathol, 72, 348-350. [CrossRef]

Salim H.A., S. Simon and A.A. Lal .2017. Integrated diseases management (IDM) against tomato (Lycopersicon esculentum L.) Fusarium wilt. Journal Environment Agricultural Sciences 11: 29-34. 
Samarrai, F. H. S.2002. Effect of Trichoderma spp isolates on seed germination and growth of Sour orange seedlings (Citrus aurantium). Master Thesis - Department of Horticulture and Garden Engineering - College of Agriculture - University of Baghdad.

Sambrook, J., E.F Fritch and J. Maniatis. 1989. Molecular cloning, laboratory Manual. $2^{\text {nd }}$ edition. Cold spring Harbor laboratory press, New York.

Scott , J. B. and S.Chakrabortey.2010. Genotypic diversity in Fusarium pseudograminearum populations in Australian wheat fields. Plant Pathology,59:338-377.

Smiley, R.W., J. A. Gourlie, S. A. Easley, L.M. Patterson and R.G. Whittaker. 2005. Crop damage estimates for crown rot of wheat and barley in the Pacific Northwest. Plant Disease 89: 595-604.

Stolp, H. and D. Gadkari. 1984. Nonpathogenic members of the genus Pseudomonas , In: The Prokaryotes ( Eds , Starr, P. M., Truner , H. G., Balaws, A. and Schlegel, H. G ) pp 719-740. Vol 1.

Tuzun, S. and J. Kloepper. 1995. Practical application and implementation of induced resistance. In Hammerschmidtt R. and J. Kuc (eds) induced resistance to disease in plants (pp152-168). Kluwer Academic Press, Dordrechet.

Wollum-II, A. G. 1982. Cultural methods for soil microorganisms. In: Methods of Soil Analysis: Chemical and Microbial Properties, $2^{\text {nd }}$ Edn. ed. Page, A. L., Miller, R. H. and Keeny, D. R. pp. 718-802.

Zamanizadeh, N., H. R. Hataml, M.M. Aminaee, F. Rakhshandehroo. 2010. Application of biofungicides in control disease damping off in greenhouse crops as a possible substitute to synthetic fungicides International Journal of Environmental Science and Technology. 8. 129-136. 